\title{
Establishment and Optimization Growth of Shoot Buds-Derived Callus and Suspension Cell Cultures of Kaempferia parviflora
}

\author{
Ab Rahman Zuraida1, Othman Ayu Nazreena1, Kamarulzaman Fatin Liyana Izzati' \\ Ahmad Aziz 2 ,3 \\ ${ }^{1}$ Biotechnology Research Centre, MARDI Headquarters, MARDI HQ, Persiaran MARDI-UPM, Serdang, Malaysia \\ ${ }^{2}$ School of Science and Food Technology, Kuala Terengganu, Malaysia \\ ${ }^{3}$ Centre for Fundamental and Liberal Education, Universiti Malaysia Terengganu, Kuala Terengganu, Malaysia \\ Email: azuraida@mardi.gov.my, aaziz@umt.edu.my
}

Received 10 June 2014; revised 16 July 2014; accepted 6 August 2014

Copyright (C) 2014 by authors and Scientific Research Publishing Inc.

This work is licensed under the Creative Commons Attribution International License (CC BY).

http://creativecommons.org/licenses/by/4.0/

(c) (i) Open Access

\begin{abstract}
Callus and suspension cells culture of Kaempferia parviflora was successfully established. Meristematic shoots can be used for utilization of plant cell biosynthetic capabilities for obtaining useful products from valuable medicinal plant to meet out the pharmaceutical demand and also for studying the metabolism. The medium containing combination of $0.2 \mathrm{mg} / \mathrm{L}$ 2,4-dichlorophenoxyacetic acid (2,4-D) and $0.2 \mathrm{mg} / \mathrm{L}$ napthyleneacetic acid (NAA) promoted the highest callus induction at $20 \%$. Transferring the initiated callus on the medium with $1 \mathrm{mg} / \mathrm{L} \mathrm{2,4-D} \mathrm{enhanced} \mathrm{the} \mathrm{prolif-}$ eration rate up to maximum fresh weight of $6.71 \mathrm{gm}$. Growth curve of cultured cells revealed that the cells continued to grow until 50 days of culture and showed the highest peak (fresh weight) at 40 days in all different initial weight tested ( $0.2,0.5$ and 1.0 gram). Isolated embryogenic callus was found to produce the highest in weight when suspended in liquid medium supplemented with $1 \mathrm{mg} / \mathrm{L}$ 2,4-D at $110 \mathrm{rpm}$ resulted 13.5 gram fresh weight and $1080 \mathrm{mg}$ dry weight.
\end{abstract}

\section{Keywords}

Kaempferia parviflora, Suspension Cultures, Meristematic Shoots, Callus Induction

\section{Introduction}

Kaempferia parviflora is a ginger plant belonging to the Zingiberaceae family. It is also known as "cekur hitam" in Malay, and Krachai-dam in Thai language. The rhizome of this plant has been traditionally used in Malay and Thai medicine for promoting health, relieving body pains, leucorrhea, oral disease, gastrointestinal disorders,

How to cite this paper: Zuraida, A.R., Nazreena, O.A., Izzati, K.F.L. and Aziz, A. (2014) Establishment and Optimization Growth of Shoot Buds-Derived Callus and Suspension Cell Cultures of Kaempferia parviflora. American Journal of Plant Sciences, 5, 2693-2699. http://dx.doi.org/10.4236/ajps.2014.518284 
and rectifying male impotence [1]-[4]. Phytochemical studies revealed that the rhizomes of $K$. parvifora contains volatile oil [5], phenolic glycoside [6] and many flavonoids including flavones, flavanones and chalcones [1] [7]. Previous studies demonstrated K. parviflora to possessed antifungal, anti-plasmodial, anti-fungal, antimycobacterial [1], anti-gastric ulcers [2], anti-allergic [3], anti HIV-1 [8] and anti-ace tylcholine-esterase (AChE) activities [9]. The ethanolic extract and 5-hydroxy-3,7,3',4',-tetramethoxyflavone of this plant exhibited appreciable inhibitory effects on nitric oxideand PGE2 release from murine macrophage cells [3]. Traditionally, rhizome of $K$. parviflora has been used as herbal medicine to alleviate male impotence [4]. Even though its mechanism of action is not known, recent in vitro study indicated that it may be mediated through cGMP by promoting inhibition of phosphodiesterase type 5 (PDE-5) activity, which breaks down cGMP by cleaving it to 5'-GMP [10]. Oral administration of this plant also significantly prevents UVB-induced photo aging in hairless mice [11].

An efficient micro-propagation protocol for K. parviflora has been established [12]. The terminal buds cultured on MS medium supplemented with $7 \mathrm{mg} / \mathrm{L}$ 6-benzylaminopurine produced 5 shoots per initial explants after 8 weeks of culture. It's a suitable source of planting materials for production of biologically active chemicals. Asan alternative, the callus and suspension cells techniques may also be applied to replace plantation systems. The key are technical and economic feasibility rests on the ability to induce and select genetically stable whole plants or cell cultures that overproduce specific chemicals and the development of scale-up technology that exploits the biological capabilities of plant cells and promotes efficient production. Such technology also allows manipulation of medium and culture condition. To date, callus and suspension cells culture of several ginger species family has been successfully established [13]-[15]. Therefore, the objective of this study is to establish a protocol for proliferation of callus and suspension cells culture of $K$. parviflora, which can be a source for secondary metabolites production.

\section{Material and Methods}

\subsection{Plant Materials and Culture Condition}

Rhizomes of Kaempreria parviflora were obtained from Ladang Mak Yah nursery in Temerloh Pahang, Malaysia. They were then cultivated in the glasshouse to allow sprouting of immature buds. The temperature in glasshouse were $29^{\circ} \mathrm{C} \pm 3^{\circ} \mathrm{C}$ with a 12L:12D photoperiod and the relative humidity fluctuated between $50 \%-70 \%$. Buds of immature sprouts were collected and used as the source of explants. Immature buds were cleaned under running tap water for an hour then washed with commercial laboratory detergent (Decon $5 \%(\mathrm{v} / \mathrm{v})$ and rinsed thoroughly with tap water. Explants were then immersed in 1\% (v/v) fungicide (Benomyl 50\%, Benlate ${ }^{\circledR}$ ) for one hour and rinsed thoroughly under running tap water for 5 min. Subsequently, under aseptic condition, explants were surface sterilized in $20 \%$ clorox $^{\circledR}$ added with a few drops of Tween-20 for $30 \mathrm{~min}$ and rinsed several times with sterilized distilled water. The sterilized explants were inoculated onto MS medium supplemented with $3 \%$ sucrose with $5.0 \mathrm{mg} / \mathrm{L}$ BAP. The in vitro plantlets obtained after 3 - 4 months sub-cultured and (Figure 1(a) and Figure 1(b)) were excised used as explants for the callus induction. In this experiment, MS [16] basal media was used. The medium was supplemented with PGRs, $3 \%(\mathrm{w} / \mathrm{v})$ sucrose, adjusted to $\mathrm{pH} 5.8$, solidified with $0.3 \%(\mathrm{w} / \mathrm{v})$ gelrite and sterilized by autoclaving at $121^{\circ} \mathrm{C}$ and $104 \mathrm{kPa}$ for $15 \mathrm{~min}$. All cultures were incubated in culture room provided with white fluorescent light at intensity of 3000 lux at a photoperiodic $16 \mathrm{~h}$. The room temperature was maintained at $25^{\circ} \mathrm{C} \pm 2^{\circ} \mathrm{C}$.

\subsection{Callus Induction and Proliferation}

Shoot buds (Figures 1(a)-(c)) were excised from in vitro plantlets and used as explants. Explants were cultured on callus induction medium (Table 1) containing MS basal medium and various combination of 2,4-D (0.2 - 2.0 $\mathrm{mg} / \mathrm{L})$ with NAA $(0.2-2.0 \mathrm{mg} / \mathrm{L})$. Cultures were monitored daily. The percentage of explants produced callus and day of callus formed were scored as amount of callus produced at every seven days intervals. The day that first explants produced callus was considered as the faster's period for callus induction. The growth of callus was optimised by transferring the healthy callus onto fresh medium contained 2,4-D and NAA (Table 2). The fresh and dry weights of callus were recorded after 40 days of culture.

\subsection{Establishment of Suspension Cell Cultures}

Suspension cell cultures was initiated from healthy, friable and soft callus maintained on medium containing 1.0 


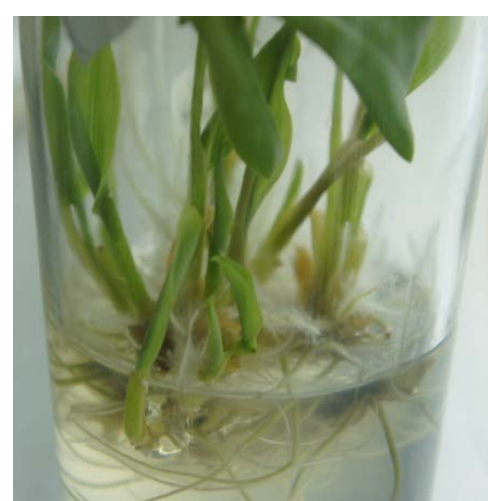

(a)

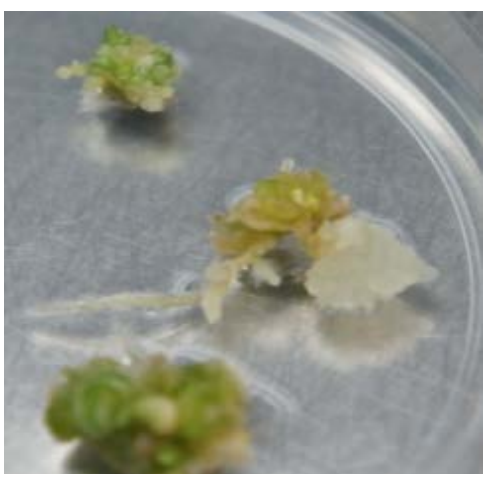

(d)

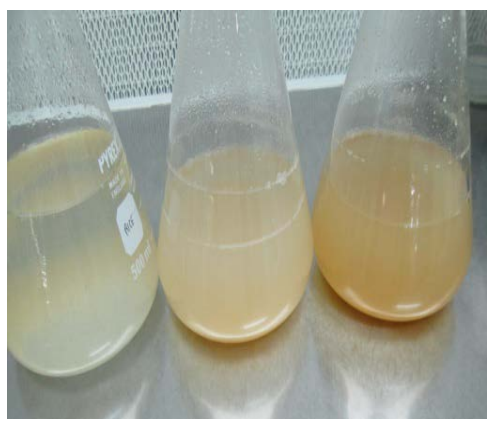

(g)

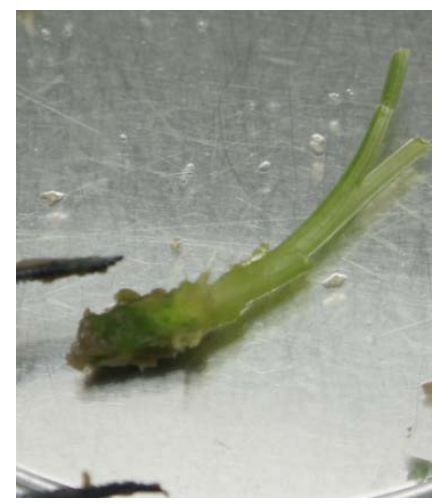

(b)

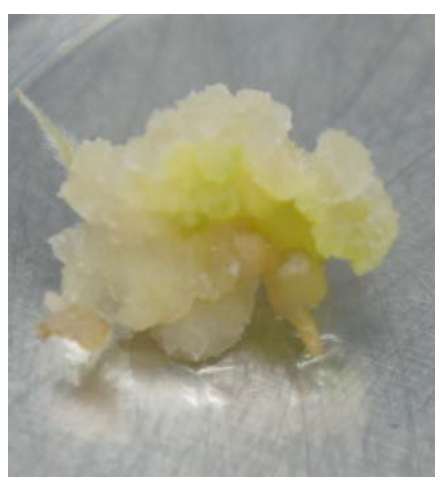

(e)

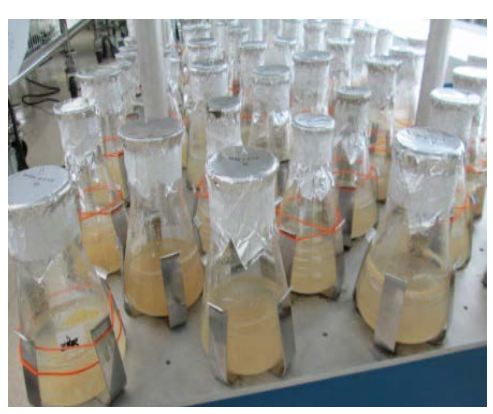

(h)

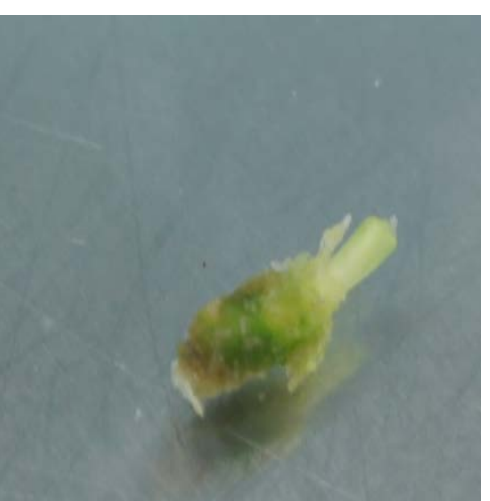

(c)

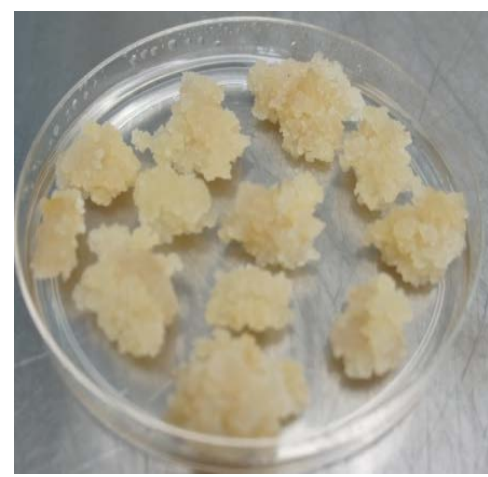

(f)

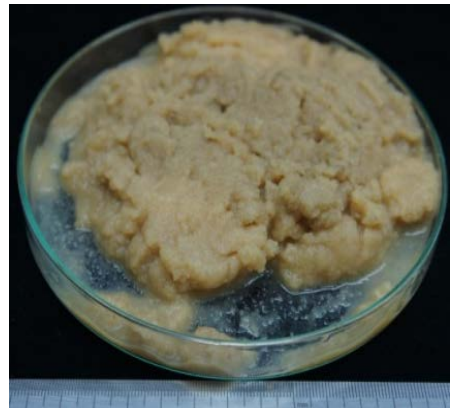

(i)

Figure 1. The in vitro plantlet of Kaempria parviflora (a)-(c) explant used for induction of calli, emergence of calli on the explants (d); whitish and fibrous calli (e); proliferated calli (f); suspension cell culture initiated from various size of inoculums (g); suspension cell culture during optimization process (h) and biomass of suspension cells at harvest (i).

mg/L 2,4-D, which medium that yielding optimal callus proliferation. A $150 \mathrm{~mL}$ Erlenmeyer flasks containing $40 \mathrm{~mL}$ of liquid MS medium supplemented with $0.2 \mathrm{mg} / \mathrm{L} \mathrm{2,4-D} \mathrm{+} 0.2 \mathrm{mg} / \mathrm{L}$ NAA were inoculated with fresh calli at $0.5(0.2 \mathrm{~g}), 1.25(0.5 \mathrm{~g})$ or $2.5 \%(\mathrm{w} / \mathrm{v})(1 \mathrm{~g})$, respectively and incubated in culture room on orbital shaker with continuously shaken at $110 \mathrm{rpm}$. The fresh weight of cells was measured at every 10 days internal until the growth reached the stationary phase. Subsequently, cells at the early stationary growth-phase were sub-cultured into optimization medium containing with various concentrations of 2,4-D and/or NAA (Table 3). Cells were grown until reached the stationary stage (50 days). At harvested, cells the biomass was determined.

\subsection{Statistical Analysis}

The data were subjected to one way analysis of variance (ANOVA) to assess treatment differences and interaction using the SPSS version 11.0 significance between means was tested by DMRT’s Test ( $\mathrm{p} \leq 0.05)$. This ex- 
Table 1. Effect of combination of 2,4-D with NAA on formation callus from meristematic shoot of Kaempreria parviflora after 3 months of culture.

\begin{tabular}{|c|c|c|c|c|}
\hline 2,4-D (mg/L) & NAA (mg/L) & $\%$ of explants induce callus formation (\%) & Days of callus formation & Callus scoring \\
\hline \multirow{4}{*}{0.2} & 0.2 & $20 \pm 4.5$ & 95 & ++++ \\
\hline & 0.5 & $15 \pm 1.2$ & 100 & +++ \\
\hline & 1.0 & $13 \pm 1.6$ & 100 & + \\
\hline & 2.0 & 0 & - & - \\
\hline \multirow{4}{*}{0.5} & 0.2 & $11 \pm 2.3$ & 95 & +++ \\
\hline & 0.5 & $10 \pm 1.0$ & 95 & ++ \\
\hline & 1.0 & $0.5 \pm 0.1$ & 100 & + \\
\hline & 2.0 & $0.5 \pm 0.1$ & 100 & + \\
\hline \multirow{4}{*}{1.0} & 0.2 & $10 \pm 2.1$ & 95 & ++ \\
\hline & 0.5 & $5 \pm 0.7$ & 100 & ++ \\
\hline & 1.0 & $0.5 \pm 0.1$ & 100 & + \\
\hline & 2.0 & $0.5 \pm 0.1$ & 110 & - \\
\hline \multirow{4}{*}{2.0} & 0.2 & $5 \pm 0.9$ & 100 & + \\
\hline & 0.5 & $5 \pm 0.5$ & 100 & + \\
\hline & 1.0 & $1 \pm 0.5$ & 120 & + \\
\hline & 2.0 & 0 & - & - \\
\hline
\end{tabular}

Results represent mean \pm standard error mean $(\mathrm{SEM})$ of 25 replicated $(\mathrm{p} \leq 0.05)$. Note: ++++ vigorous callus produced; ++ intermediate callus; + less callus; - no callus.

periment with 25 replications per treatments.

\section{Results and Discussion}

\subsection{Effect of Exogenous Plant Growth Regulators on Callus Formation and Proliferation}

Results showed that all culture media used were suitable for callus induction using shoot buds explants, with exception $2.0 \mathrm{mg} / \mathrm{L}$ NAA (Table 1) (Figures 1(d)-(f)). The greatest number of callus forming was obtained in $0.2 \mathrm{mg} / \mathrm{L} 2,4-\mathrm{D}+0.2 \mathrm{mg} / \mathrm{L}$ NAA, where the percentage of callus forming were $20 \%$ after 95 days inoculated onto the treatment medium. The number of explants forming was decreased as the concentration of 2,4-D or NAA increases. In these media, time for callogenesis was also delayed (Table 1). As example, explants culture in $2.0 \mathrm{mg} / \mathrm{L}$ 2,4-D + $1.0 \mathrm{mg} / \mathrm{L}$ NAA taken 120 days before fist callus in generated. The callus was soft in texture, friable in structure and yellowish white (Figure 1(e), Figure 1(f)). These results not much differed from those of [17] [18], who obtained callus from young leaves of Cornukaempferia larsenii and Cornukaempferia aurantiolia on MS medium supplemented with various concentrations of 2,4-D in light and dark conditions. They stated that callus forming was from the basal part of the explants which contained the meristematic tissue. Callus forming from various tissues were morphologically different. It response were depends on the chemical nature, the combination and concentration of plant growth regulator and varies between genotype [19]. They have reported that, soft and friable were calli developed from shoot primordia, hard and compact calli developed from 2 weeks old buds of Zingiber officinale cultured on medium MS medium contains $0.5 \mathrm{mg} / \mathrm{L}$ BAP and $0.5 \mathrm{mg} / \mathrm{L}$ 2,4-D. Embryogenic callus was formed from rhizome with vegetative buds of Kaempferia galanga cultured on MS medium supplemented with $0.5 \mathrm{mg} / \mathrm{L}$ BAP and $1.0 \mathrm{mg} / \mathrm{L}$ 2,4-D [20]. Dicamba (2 mg/L), picloram (2 mg/L) or NAA (5 mg/L) combined with BA $(0.5 \mathrm{mg} / \mathrm{L})$ were to induce callus from leaf base of Curcuma longa [15]. Effect of 2,-4 D and NAA on the proliferation of $K$. parviflora callus in shown in Table 2. Based on biomass, 
Table 2. Effect of 2,4-D and NAA on biomass of Kaempferia parviflora callus after 40 days of culture.

\begin{tabular}{|c|c|c|c|}
\hline 2,4-D (mg/L) & NAA (mg/L) & Fresh weight of callus (g) & Dry weight of callus (mg) \\
\hline 0.2 & - & $3.52 \pm 0.22$ & $130 \pm 25$ \\
\hline 0.5 & - & $5.11 \pm 0.71$ & $210 \pm 30$ \\
\hline 1.0 & - & $6.71 \pm 0.58$ & $540 \pm 70$ \\
\hline 2.0 & - & $4.01 \pm 0.54$ & $230 \pm 34$ \\
\hline- & 0.2 & $3.11 \pm 0.32$ & $90 \pm 20$ \\
\hline- & 0.5 & $3.21 \pm 0.44$ & $110 \pm 35$ \\
\hline- & 1.0 & $5.24 \pm 0.78$ & $320 \pm 40$ \\
\hline- & 2.0 & $6.41 \pm 1.09$ & $390 \pm 60$ \\
\hline- & 5.0 & $6.11 \pm 0.10$ & $410 \pm 55$ \\
\hline 0.2 & 0.2 & $3.80 \pm 0.55$ & $180 \pm 35$ \\
\hline 0.2 & 0.5 & $5.51 \pm 0.51$ & $280 \pm 30$ \\
\hline 0.2 & 1.0 & $4.12 \pm 0.45$ & $270 \pm 25$ \\
\hline 0.5 & 0.2 & $4.04 \pm 0.34$ & $230 \pm 30$ \\
\hline 0.5 & 0.5 & $4.55 \pm 0.67$ & $140 \pm 20$ \\
\hline 0.5 & 1.0 & $3.71 \pm 0.33$ & $130 \pm 20$ \\
\hline 1.0 & 0.2 & $3.24 \pm 0.45$ & $210 \pm 35$ \\
\hline 1.0 & 0.5 & $3.91 \pm 0.31$ & $190 \pm 26$ \\
\hline 1.0 & 1.0 & $4.61 \pm 0.89$ & $230 \pm 27$ \\
\hline
\end{tabular}

Results represent mean \pm standard error mean (SEM) of 25 replicated $(\mathrm{p} \leq 0.05)$.

the highest proliferation of callus was in $1.0 \mathrm{mg} / \mathrm{L} \mathrm{2,4-D.} \mathrm{It} \mathrm{was} 6.71 \mathrm{~g}$ and $540 \mathrm{mg}$ of fresh and dry weight, respectively. Callus cultured in 2.0 and 5.g mg/L NAA exhibited the second highest of callus proliferation. Interestingly, callogenesis was preferred combination of 2,4-D with NAA at lower concentrations, while callus proliferation in higher 2,4-D concentration, singly. Addition of NAA in the medium is useful to avoid the formation of embryogenic callus [21]. It have stated that NAA had no effect on the embryogenic callus induction, but Kinetin facilitated the effect of 2,4-D on embryogenic callus induction in Zingiber officinale.

\subsection{Establishment of Suspension Cell Culture}

Suspension cell cultures of $K$. parviflora were easily established from the proliferated calli (Figure 1(g), Figure 1(h)). Results showed that initial weight calli used as inoculum were significantly influenced the proliferation of suspension cells (Figure 2). The highest fresh weight of cells (16 $\pm 0.6 \mathrm{~g}$ ) was obtained from $1.0 \mathrm{~g}$ calli (2.5\% $\mathrm{w} / \mathrm{v})$ as inoculum. It was16-fold increment after 50 days of culture. In the other hand, fresh weight of cells initiated from $0.5 \mathrm{~g}(1.25 \% \mathrm{w} / \mathrm{v})$ and $0.2 \mathrm{~g}(0.5 \% \mathrm{w} / \mathrm{v})$ calli was $14 \mathrm{~g}$ and $13 \mathrm{~g}$, respectively. This is equivalent to 28and 130-fold higher from the initial weight. All cultures exhibited the proliferation phase between 20 to 40 days of culture and reached the stationary phase after 40 days of culture. Small size of inoculum means small number of cells was transferred into culture medium. Thus, this phenomenon suggesting that K. parviflora suspension cell culture contains lower cells density possesses higher cells proliferation rate. [21] reported that cells proliferation was slow in ginger suspension cell cultures when the amount of inoculated cells lower than $0.5 \%(w / v)$, but it highly proliferated when more than $2.0 \%(\mathrm{w} / \mathrm{v})$ cells were inoculated. The size inoculum was also greatly affected cell vitalities in further subcultures of ginger suspension cultures. These quickly proliferated cells were rapidly browned due to fast consumption of oxygen and nutrition [21].

Results on the optimization of culture medium for proliferation of suspension cell cultures are shown in Table 3. 
Table 3. Effect of 2,4-D and NAA on biomass of suspension cells culture after 50 days of culture.

\begin{tabular}{|c|c|c|c|}
\hline 2,4-D (mg/L) & NAA (mg/L) & Fresh weight of suspension cultures (g) & Dry weight of suspension cultures (mg) \\
\hline 0.2 & & $6.2 \pm 0.5$ & $510 \pm 60$ \\
\hline 0.5 & & $11.2 \pm 1.2$ & $910 \pm 80$ \\
\hline 1.0 & & $13.5 \pm 0.9$ & $1080 \pm 80$ \\
\hline 2.0 & & $9.1 \pm 1.5$ & $820 \pm 70$ \\
\hline 3.0 & & $6.1 \pm 2.4$ & $570 \pm 24$ \\
\hline 5.0 & & $5.3 \pm 2.3$ & $420 \pm 55$ \\
\hline \multirow{3}{*}{0.2} & 0.2 & $9.2 \pm 1.3$ & $710 \pm 85$ \\
\hline & 0.5 & $7.4 \pm 1.5$ & $590 \pm 65$ \\
\hline & 1.0 & $6.1 \pm 2.4$ & $410 \pm 35$ \\
\hline \multirow{3}{*}{0.5} & 0.2 & $8.9 \pm 1.1$ & $760 \pm 110$ \\
\hline & 0.5 & $7.4 \pm 0.7$ & $590 \pm 25$ \\
\hline & 1.0 & $8.6 \pm 1.1$ & $610 \pm 45$ \\
\hline \multirow[t]{2}{*}{1.0} & $\begin{array}{l}0.2 \\
0.5\end{array}$ & $\begin{array}{c}10.2 \pm 0.9 \\
8.6 \pm 2.1\end{array}$ & $\begin{array}{c}720 \pm 120 \\
640 \pm 70\end{array}$ \\
\hline & 1.0 & $5.2 \pm 0.6$ & $310 \pm 65$ \\
\hline
\end{tabular}

Results represent mean \pm standard error mean (SEM) of 25 replicated $(\mathrm{p} \leq 0.05)$.

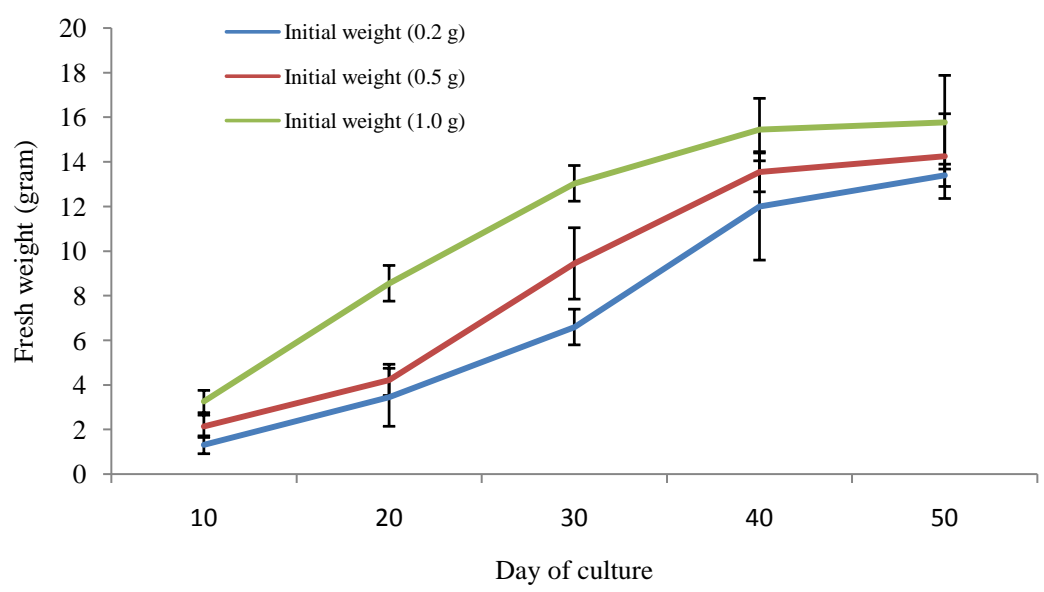

Figure 2. Effect of initial weight of cells on growth of suspension cell culture for 50 days of culture. Results represent mean \pm standard error mean (SEM) of 25 replicated $(\mathrm{p} \leq 0.05)$.

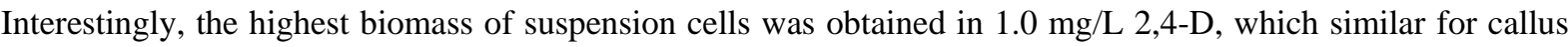
proliferation. However, the final weight of biomass of suspension cell cultures was 2-fold higher than callus in the same medium. This finding shows the feasibility of suspension cell cultures for production of biomass of $K$. parviflora under controlled environment.

\section{Conclusion}

Callus of K. parviflora was easily established from the meristem shoot bud of in vitro plantlets. The optimum medium for proliferation of callus and suspension cell culture for this plant was $1.0 \mathrm{mg} / \mathrm{L}$ 2,4-D. Suspension cell cultures demonstrated higher proliferation rate than callus culture. 


\section{References}

[1] Yenjai, C., Prasanphen, K., Daodee, S., Wongpanich, V. and Kittakoop, P. (2004) Bioactive Flavonoids from Kaempferia parviflora. Fitoterapia, 75, 89-92. http://dx.doi.org/10.1016/j.fitote.2003.08.017

[2] Rujjanawate, C., Kanjanapothi, D., Amornlerdpison, D. and Pojanagaroon, S. (2005) Anti-Gastric Ulcer Effect of Kaempferia parviflora. Journal of Ethnopharmacology, 102, 120-122. http://dx.doi.org/10.1016/j.jep.2005.03.035

[3] Tewtrakul, S., Subhadhirasakul, S. and Kummee, S. (2008) Anti-Allergic Activity of Compounds from Kaempferia parviflora. Journal of Ethnopharmacology, 116, 191-193. http://dx.doi.org/10.1016/j.jep.2007.10.042

[4] Trisomboon, H. (2009) Kaempferia parviflora: A Thai Herbal Plant, Neither Promote Reproductive Function Nor Increase Libido via Male Hormone. Thai Journal of Physiological Sciences, 21, 83-86.

[5] Wongsinkongman, P., Mongkolchaipak, N., Chansuvanich, N., Techadumrongsin, Y. and Boonruad, T. (2003) Quality Evaluation of Crude Drugs and Volatile Oil of Krachai-Dam Rhizomes. Bulletin of the Department of Medical Sciences, 45, 1-16.

[6] Azuma, T., Tanaka, Y. and Kikuzaki, H. (2008) Phenolic Glycosides from Kaempferia parviflora. Phytochemistry, 69, 2743-2748. http://dx.doi.org/10.1016/j.phytochem.2008.09.001

[7] Sutthanut, K., Sripanidkulchai, B., Yenjai, C. and Jay, M. (2007) Simultaneous Identification and Quantitation of 11 Flavonoid Constituents in Kaempferia parviflora by Gas Chromatography. Journal of Chromatography A, 1143, 227233. http://dx.doi.org/10.1016/j.chroma.2007.01.033

[8] Sookkongwaree, K., Geitman, M., Roengsumran, S., Petsom, A. and Danielson, U.N. (2006) Inhibition of Viral Proteases by Zingiberaceae Extracts and Flavones Isolated from Kaempferia parviflora. Die Pharmazie, 61, 717-721.

[9] Sawasdee, P., Sabphon, C., Sitthiwongwanit, D. and Kokpol, U. (2009) Anticholinesterase Activity of 7-Methoxyflavones Isolated from Kaempferia parviflora. Phytotherapy Research, 23, 1792-1794. http://dx.doi.org/10.1002/ptr.2858

[10] Rosen, R.C. and Kostis, J.B. (2003) Overview of Phosphodiesterase 5 Inhibition in Erectile Dysfunction. American Journal of Cardiology, 92, 9-18. http://dx.doi.org/10.1016/S0002-9149(03)00824-5

[11] Park, J.E., Pyun, H.B., Woo, S.W., Jeong, J.H. and Hwang, J.K. (2014) The Protective Effect of Kaempferia parviflora Extract on UVB-Induced Skin Photoaging in Hairless Mice. Photodermatology, Photoimmunology \& Photomedicine, Early View. http://onlinelibrary.wiley.com/doi/10.1111/phpp.12097/pdf

[12] Prathanturarug, S., Apichartbutra, T., Chuakul, W. and Saralamp, P. (2000) Mass Propagation of Kaempferia parviflora Wall ex Baker by in Vitro Regeneration. Journal of Horticultural Science and Biotechnology, 82, 179-183.

[13] Shirin, A.P.R. and Jamuna, P. (2010) Chemical Composition and Antioxidant Properties of Ginger Root (Zingiber officinale). Journal of Medicinal Plants Research, 4, 2674-2679.

[14] Mello, M.O., Amaral, A.F.C. and Melo, M. (2000) Quantificação da micropropagação de Curcuma zedoaria Roscoe. Scientia Agricola, 57, 703-707. http://dx.doi.org/10.1590/S0103-90162000000400016

[15] Salvi, N.D., George, L. and Eapen, S. (2001) Plant Regeneration from Leaf Base Callus of Turmeric and Random Amplified Polymorphic DNA Analysis of Regenerated Plants. Plant Cell, Tissue and Organ Culture, 66, 113-119. http://dx.doi.org/10.1023/A:1010638209377

[16] Murashige, T. and Skoog, F. (1962) A Revised Medium for Rapid Growth and Bio Assays with Tobacco Tissue Cultures. Physiologia Plantarum, 15, 473-497. http://dx.doi.org/10.1111/j.1399-3054.1962.tb08052.x

[17] Saensouk, P. (2011) Callus Induction and Plant Regeneration from Leaf Explant of Cornukaempferia aurantiflora Mood \& Larsen. Pakistan Journal of Botany, 43, 2415-2418.

[18] Saensouk, P., Theerakulpisut, P., Kijwijan, B. and Bunnag, S. (2007) Effects of 2,4-D on Callus Induction from Leaf Explants of Cornukaempferia larsenii P. Gardens' Bulletin, 59, 183-188.

[19] Ilahi, I. and Jabeen, M. (1987) Micropropagation of Zingiber officinale L. Pakistan Journal of Botany, 19, 61-65.

[20] Vincent, K.A., Hariharan, M. and Mathew, K.M. (1992) Embryogenesis and Plantlet Formation in Tissue Culture of Kaempferia galangal L.: A Medicinal Plant. Phytomorphology, 42, 253-256.

[21] Guo, Y.H. and Zhang, Z.X. (2005) Establishment and Plant Regeneration of Somatic Embryogenesis Cell Suspension Cultures of the Zingiber officinale Rosc. Scientia Horticulturae, 107, 90-96. http://dx.doi.org/10.1016/j.scienta.2005.07.003 
Scientific Research Publishing (SCIRP) is one of the largest Open Access journal publishers. It is currently publishing more than 200 open access, online, peer-reviewed journals covering a wide range of academic disciplines. SCIRP serves the worldwide academic communities and contributes to the progress and application of science with its publication.

Other selected journals from SCIRP are listed as below. Submit your manuscript to us via either submit@scirp.org or Online Submission Portal.
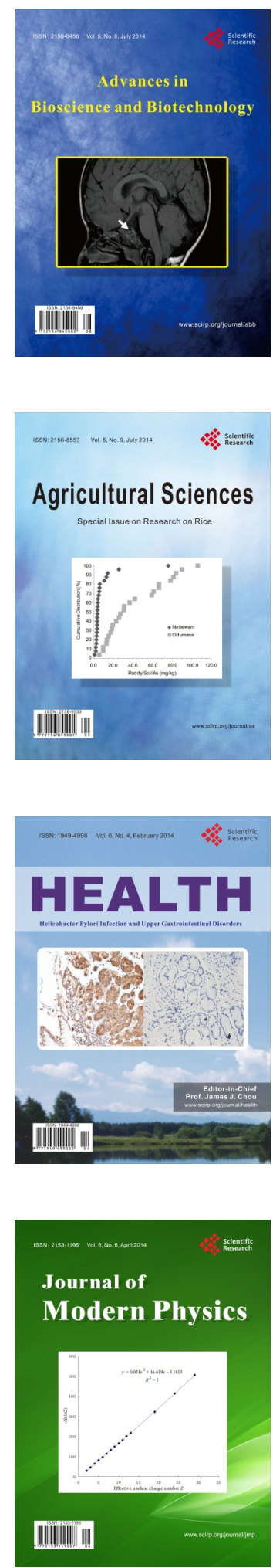
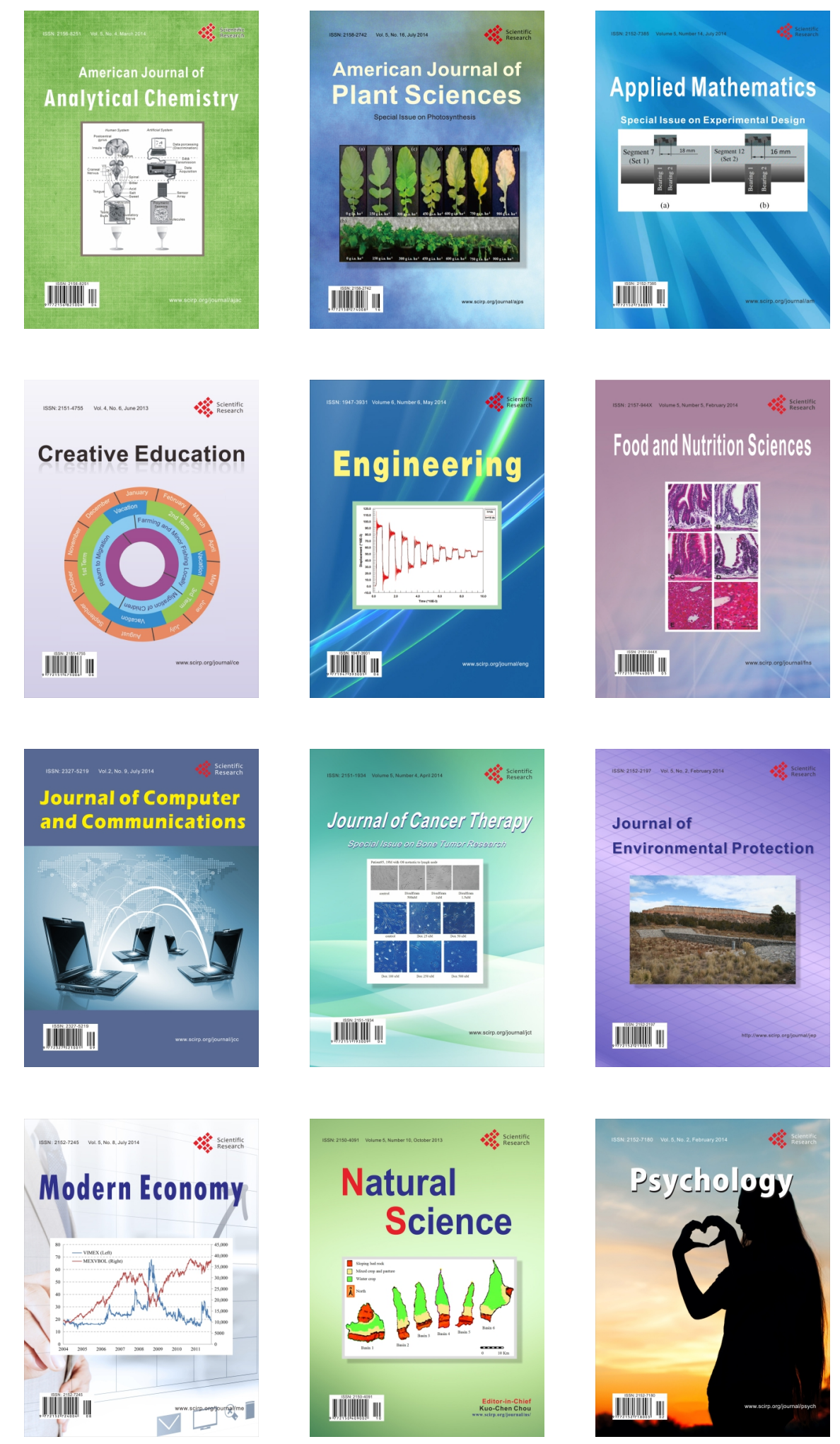